\title{
Spatial and Temporal Distribution of a Biocontrol Bacterium Bacillus licheniformis N1 on the Strawberry Plants
}

\author{
Hyun Gi Kong ${ }^{1 \dagger}$, Hyoung Ju Lee ${ }^{1 \dagger}$, Ju Young Bae ${ }^{2}$, Nam Hee Kim ${ }^{1}$, Byung Ju Moon ${ }^{1}$ and Seon-Woo Lee ${ }^{1,2 *}$ \\ ${ }^{1}$ Department of Applied Biology, Dong-A University, Busan 604-714, Korea \\ ${ }^{2}$ Department of Medical Bioscience, Dong-A University, Busan 604-714, Korea \\ (Received on July 26, 2010; Accepted on August 21, 2010)
}

Spatial and temporal distribution of Bacillus licheniformis N1 was investigated over time on the leaves, petioles and crowns of the strawberry plants. Bacterial population on the strawberry plants was quantified over time by selective plating. Bacterial population of N1 containing a plasmid pWH43G carrying green fluorescent protein (GFP) declined relatively faster on the plant surface as compared to the Strain N1 itself. However, this result was found to be enough to utilize the strain to visualize bacterial colonization on the plant surface. When B. licheniformis N1 was treated together with Silwet $\mathrm{L}-77$ at $0.03 \%$, the bacterial population on plant surface persisted for up to 7 days. B. licheniformis N1 (pWH43G) containing Silwet L-77 was applied on the strawberry plants and the GFP expressing bacteria were visualized by confocal laser scanning microscopy. Bacterial persistence was also investigated in a growth chamber and in a plastic house after N1 bioformulation treatment on the strawberry plant. The Strain N1 colonized three different tissues well and persisted over 3 to 5 days on the strawberry plants. They formed bacterial aggregates on plant surfaces for at least 3 days, resulting in a biofilm to resist fluctuating plant surface environment. However, the bacterial persistence dramatically declined after 7 days in all tested tissues in a plastic house. This study suggest that $B$. licheniformis N1 colonizes the strawberry plant surface and persists for a long time in a controlled growth chamber, while it can not persist over 7 days on the plant surface in a plastic house.

Keywords : Bacillus licheniformis, biocontrol agent, colonization, distribution, persistence, strawberry

Biological control of plant disease, as an alternative to chemical control of plant disease, has been considered a promising method for safe crop-management practices in an environmentally friendly manner (Cook, 1993; Fravel,

\footnotetext{
*Corresponding author.

Phone) +82-51-200-7551, FAX) +82-51-200-7505

E-mail)seonlee@dau.ac.kr

${ }^{\dagger}$ Equally contributed
}

2005). Various biofungicides using antagonistic microorganisms have been developed and applied to the agricultural ecosystems to control plant diseases (Fravel et al., 1998; Schisler et al., 2004). Although some of the developed biofungicides have been effective in controlling a range of plant diseases, a number of these developed biofungicide applications frequently resulted in poor performance for effective disease control (Cook, 1993; Mathre et al., 1999). It is generally recognized that biological control of plant disease is the result of complex interactions between the biocontrol agent, the pathogen, the host plant and the environment. Especially, when the biocontrol agents applied to the phyllosphere, the commercialization of the biofungicides for use to control foliar pathogen is low (Collins et al., 2003). Rapidly fluctuating environment of the phyllosphere may affect the performance of the biocontrol agent for controlling the plant disease. The phyllosphere has been considered a relatively harsh environment for bacterial colonization (Lindow and Brandl, 2003). For the successful biological control of foliar plant diseases, the rate of bacterial colonization on the plant tissues and the time that biocontrol agent remains active are important factors in determining the performance of a biocontrol method (Jeger et al., 2009). Therefore, the bacterial population dynamics, such as colonization and persistence, needs to be investigated to understand the bacterial activity on the plant surface environment before the commercialization of the biocontrol agent for use to control plant disease.

Bacillus licheniformis N1 has been used as a biocontrol agent against some plant diseases. Previously, we successfully developed effective formulations of biofungicide with antagonistic B. licheniformis N1 to control tomato and strawberry gray mold (Kim et al., 2007; Lee et al., 2006). Strawberry, one of the important cash crops in Korea, is frequently grown in controlled plastic houses during winter season. Several foliar pathogens of strawberry cause severe diseases, such as gray mold caused by Botrytis cinerea, anthracnose caused by Colletotrichum spp. and powdery mildew caused by Sphaerotheca aphanis, which are important yield limiting plant diseases worldwide and in 
Korea (Maas, 1984; Nam et al., 2008). To improve biocontrol efficacy of $B$. licheniformis N1 in controlling strawberry diseases, it is important to investigate bacterial colonization and persistence on the strawberry plants. Frequently, the fungal inoculum on aerial parts (leaves and crowns) of the strawberry plant increases without any symptom development or with limited lesion development and produces many secondary inoculums for disease spread (Braun and Sutton, 1988; Howard et al., 1992). Therefore, efficient suppression of the primary fungal inoculums on the plant surface would be the first step in managing many important foliar plant diseases on the strawberry plant. More efficient formulations to enhance bacterial colonization and persistence on the strawberry phytosphere can be also designed using the strain N1 based on the ecological studies of the bacteria.

We have previously developed a biomarking system to study the bacterial ecology in a native ecosystem using the green fluorescent protein (GFP). The biomarking system included a P43 promoter from Bacillus subtilis and a $g f p$ gene fusion to constitutively express GFP in B. subtilis (Kong et al., 2009). In this study, we used strawberry plants and $B$. licheniformis Strain N1 expressing GFP to study the spatial and temporal distribution of the Strain N1. Bacterial persistence was also evaluated on the strawberry plants in a controlled environment and in a plastic house.

\section{Materials and Methods}

Bacterial culture conditions and N1E formulation. $B$. licheniformis N1 (Kim et al., 2007; Lee et al., 2006) were routinely grown at $30^{\circ} \mathrm{C}$ on nutrient agar (NA) or in nutrient broth (NB). To provide bacterial formulation, the Strain N1 was grown in Biji medium (5\% dried soybean curd residue in distilled water) for mass production. Soybean curd residue ('Biji' in Korean) was obtained from a Korean traditional tofu factory. Dried Biji was produced to make Biji medium as previously described (Kim et al., 2007; Lee et al., 2006). When needed, rifampicin $(100 \mu \mathrm{g} /$ $\mathrm{ml})$ and tetracycline $(15 \mu \mathrm{g} / \mathrm{ml})$ were supplemented in the medium for B. licheniformis Strain N1 and B. licheniformis $\mathrm{N} 1$ carrying $\mathrm{pWH} 43 \mathrm{G}$, respectively. The plasmid pWH43G was maintained in Escherichia coli $\mathrm{DH} 5 \alpha$ routinely grown on LB medium with tetracycline at $37^{\circ} \mathrm{C}$.

To investigate bacterial colonization using bacterial formulation, we used N1E formulation (Kim et al., 2007), which has been proven to be effective to control gray mold disease on the strawberry plant. N1E formulation of $B$. licheniformis N1 was prepared as described previously (Lee et al., 2006) using Biji broth culture of Strain N1. Briefly, the $400 \mathrm{ml}$ pre-culture of bacterial cells was added directly to 4 liters of Biji broth in a 7-liter jar fermenter and one liter of the grown bacterial culture was thoroughly mixed with $400 \mathrm{~g}$ of corn starch, $50 \mathrm{ml}$ of olive oil and $50 \mathrm{~g}$ of sugar as previously described (Lee et al., 2006). The prepared N1E formulations were stored at $4{ }^{\circ} \mathrm{C}$ until use.

Plant material, growth condition and bacterial application. The strawberry plants (Fragaria $x$ ananassa (L.) Duchesne) used in this study, the cultivar Akihime, were grown in a plastic house using routine cultivation practices or in a controlled growth chamber in $15-\mathrm{cm}$-diameter pots containing the commercial horticulture nurserymedia soil (Punong Co., Ltd, Korea). When grown in growth chambers, the strawberry plants were grown at $25 \pm 2{ }^{\circ} \mathrm{C}$ with 16 $\mathrm{hr}$ light and $8 \mathrm{hr}$ dark cycle with $70 \%$ relative humidity.

The colonization of $B$. licheniformis N1 wild type strain or B. licheniformis $\mathrm{N} 1$ containing $\mathrm{pWH} 43 \mathrm{G}$ was investigated on the strawberry plants. $B$. licheniformis $\mathrm{N} 1$ wild type strain or $B$. licheniformis $\mathrm{N} 1$ containing $\mathrm{pWH} 43 \mathrm{G}$ were pre-cultured in NB broth for $24 \mathrm{hrs}$ at $30^{\circ} \mathrm{C}$ and transferred to $200 \mathrm{ml}$ of NB broth and incubated for $48 \mathrm{hrs}$ until $\mathrm{A}_{600}$ reached to 0.8 . When necessary, a low surface tension, non-ionic organosilicone surfactant Silwet L-77 (GE Healthcare, Germany) was supplemented to the culture broth at the final concentration of $0.03 \%$. To treat bacterial formulation N1E on the strawberry plants, the N1E formulation was diluted 100-fold with tap water and Silwet L-77 was supplemented to the diluted solution. Either bacterial culture broth or 100-fold diluted N1E was sprayed on the strawberry plants until runoff and the treated strawberry plants were maintained in a controlled growth chamber $\left(25 \pm 2{ }^{\circ} \mathrm{C}, 70 \% \mathrm{RH}\right)$.

Bacterial application on the plants in the plastic house was conducted when the outside temperature range was 4$20^{\circ} \mathrm{C}$ and the temperature in the plastic house was $10-25^{\circ} \mathrm{C}$. Experiments in the plastic house were repeated twice during the indicated period. Strawberry plants at the 3-5 leaves stages were treated with the bacteria. The inoculated plants were maintained in a plastic house. Strawberry plants from independent pots were randomly removed to harvest leaves, crowns and petioles. Plant sampling after one hour of the bacterial application represented the initial population of the treated bacteria. The sampling continued at different times up to 7 days or 20 days after the bacterial application. Leaves, crowns and petioles of the strawberry plants were cut into segments. The excised tissues were weighed and resuspended in $30 \mathrm{ml}$ of saline. These suspensions were mildly sonicated in a water bath at $135 \mathrm{~W}$ and $60 \mathrm{~Hz}$ for $5 \mathrm{~min}$ (Bransonic, USA). The solutions were diluted and plated to determine the $\mathrm{cfu} / \mathrm{g}$ of plant tissues.

Transformation of $\boldsymbol{B}$. licheniformis N1. To introduce pWH1520 and pWH43G (Kong et al., 2009) into $B$. 
licheniformis N1, electroporation was performed as previously described (Xue et al., 1999). Briefly, electrocompetent cells were prepared as follows. B. licehniformis Strain N1 was grown in LB broth supplemented with $0.5 \mathrm{M}$ sorbitol at $37^{\circ} \mathrm{C}$ until $\mathrm{A}_{600}$ reached to $0.85-0.95$. The bacterial cells were extensively washed with ice-cold electroporation medium ( $0.5 \mathrm{M}$ sorbitol, $0.5 \mathrm{M}$ mannitol and $10 \%$ glycerol) and subsequently resuspended in the same medium to give a bacterial concentration of $1-1.3 \times 10^{10} \mathrm{cfu} / \mathrm{ml}$. Approximately $100 \mathrm{ng}$ of purified plasmid was mixed with $60 \mu \mathrm{l}$ of the prepared electrocompetent cells in an ice-cold cuvette. Electro-transformation protocol used was basically the same, as described previously, performed at $18 \mathrm{KV} / \mathrm{cm}$ of field strength (Lee et al., 2009).

Successful transformation was confirmed by re-purification of the plasmid from the candidate transformants and introduction into E. coli $\mathrm{DH} 5 \alpha$. The plasmid from the $E$. coli DH5a was re-isolated and digested with restriction enzymes to confirm the correct transformation of the plasmid into $B$. licheniformis N1. The selected B. licheniformis N1 transformants were stored at $-80^{\circ} \mathrm{C}$ until further experiment.

Colony PCR was also conducted to verify the bacterial transformation and identity the isolated bacteria from plants. PCR reactions in this study were carried out in a $50 \mu$ (total volume) reaction mixture which contained Taq DNA polymerase buffer (Promega Corp, USA), each deoxynucleotide triphosphate at a concentration of $200 \mu \mathrm{M}$, $1.5 \mathrm{mM} \mathrm{MgCl}_{2}$, each primer at a concentration of $1 \mu \mathrm{M}$ and 2.5 Unit of Taq DNA polymerase. Two primers P43-1 (5'TATACTAGTTGATAGGTGGTATGTTTTCGC-3') and Gfp3 (5'-GGTGCATGCCTCGAATTCCTATTTGTATAG-3') were used for PCR using the following conditions (Kong et al., 2009): an initial DNA template denaturation step at $95^{\circ} \mathrm{C}$ for $3 \mathrm{~min}$; 30 cycles consisting of denaturation at $95^{\circ} \mathrm{C}$ for $30 \mathrm{~s}$, annealing at $50^{\circ} \mathrm{C}$ for $30 \mathrm{~s}$, and extension at $72^{\circ} \mathrm{C}$ for 1 min; and a final extension step at $72^{\circ} \mathrm{C}$ for $5 \mathrm{~min}$. The PCR products were analyzed by agarose gel electrophoresis.

\section{Microscopic visualization of fluorescent $\boldsymbol{B}$. licheniformis.}

To investigate the bacterial distribution at different times on the strawberry plants, B. licheniformis N1 containing pWH43G was cultured in NB broth with tetracycline until $\mathrm{A}_{600}$ reached to 0.8. Silwet L-77 was supplemented to the culture broth at the final concentration of $0.03 \%$. The bacterial culture broth was sprayed on the strawberry plants and the plants were maintained in a controlled growth chamber $\left(25 \pm 2{ }^{\circ} \mathrm{C}, 70 \% \mathrm{RH}\right)$. Fresh plant samples (leaves, crowns and petioles) were removed from the plants and observed for GFP expressing bacterial cells. B. licheniformis $\mathrm{N} 1$ with pWH43G was visualized in plant tissues by using a model LSM510 confocal laser scanning microscope (CLSM, Carl Zeiss, Germany). The light source for excit- ing GFP was a laser that provided an excitation wavelength of $488 \mathrm{~nm}$ (Argon). Fluorescence signal from GFP was detected using the filter set for fluorescein isothiocyanate (FITC; BP 505-530 green). Image acquisitions were carried out using $\times 10$ objective and processed using the standard LSM510 software package with the CLSM system.

\section{Results}

Changes in the bacterial population on the strawberry plants. B. licheniformis N1 transformants carrying $\mathrm{pWH} 43 \mathrm{G}$ were selected and confirmed by colony PCR or by restriction analysis of the isolated plasmid DNA (data not shown). Bacterial survival and population change of $B$. licheniformis $\mathrm{N} 1$ or $B$. licheniformis $\mathrm{N} 1$ carrying $\mathrm{pWH} 43 \mathrm{G}$ were investigated in three different tissues of the strawberry plants, such as leaves, crowns and petioles, grown in a growth chamber. Quantitative data was obtained over time by selective plating on NA supplemented with rifampicin and tetracycline for Strain N1 and N1 with pWH43G, respectively (Fig. 1). No background growth was observed for rhizosphere samples from non-inoculated plants. Bacterial population of Strain N1 was stably maintained in leaves and petioles until 7 days, while decreased on the crown of the plants (Fig. 1A). When we tested with Strain N1 containing pWH43G, the bacterial population decreased over time, rapidly on the crown of the plants (Fig. 1B). This result suggests that the plasmid was not stably maintained in the Strain N1 on the plant surface in the absence of tetracycline. Both for the Strain N1 and N1 carrying pWH43G, the bacterial population was steadily declined over time, irrespective of the plant tissues.

Although B. licheniformis Strain N1 produces surfactin (Kong et al., 2010), we investigated the effect of surfactant Silwet L-77, which might play a role in bacterial colonization on the plant surface and maintain the bacterial population. The Silwet L-77 at $0.03 \%$ did not confer any harmful effect to B. licheniformis Strain N1 (data not shown). When $0.03 \%$ Silwet L-77 was treated with bacterial suspension, the initial bacterial population (approximately $10^{5}$ cfu/g of tissue) was stably maintained for over 7 days without any apparent decline in the bacterial population, irrespective of the plant tissues (Fig. 1C). This result showed that Silwet L-77 may help bacteria to be stabilized on the plant surfaces. Although we have not tested whether surfactin production from Strain N1 can contribute to the initial bacterial attachment onto the plant tissues, treatment of N1 culture broth itself resulted in the bacterial colonization on the plant surfaces (Fig. 1A).

Spatial distribution of $g f p$-labelled bacteria on strawberry plants. To investigate the spatial distribution of the 

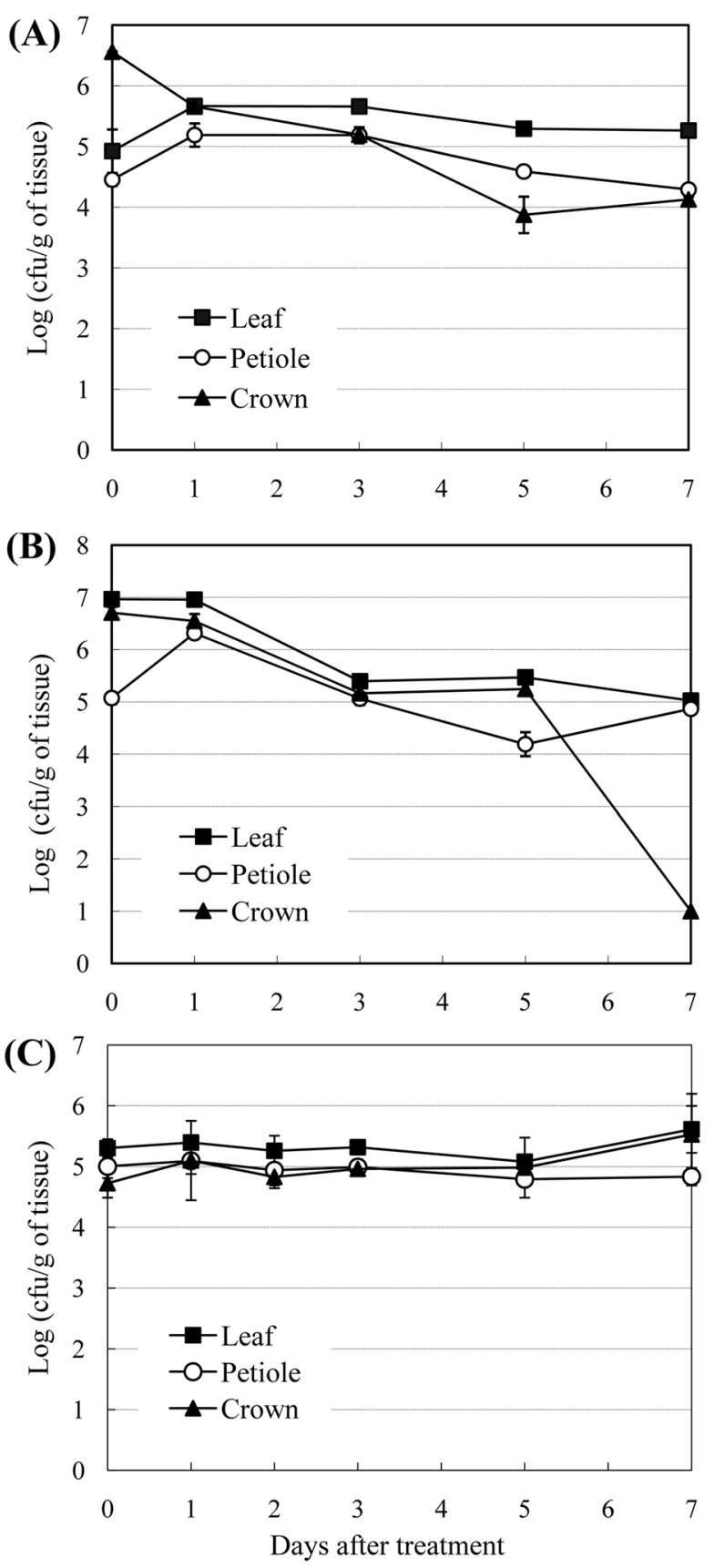

Fig. 1. Bacterial colonization of the strawberry plant tissues (leaves, crowns and petioles) in a growth chamber. (A) Bacterial population on the strawberry plant tissues treated with Bacillus licheniformis N1 wild type strain. (B) Bacterial population on the strawberry plant tissues treated with $B$. licheniformis N1 carrying pWH43G (C) Bacterial population on the strawberry plant tissues treated with Strain N1 culture suspension containing Silwet L-77 at $0.03 \%$. Error bars represent the standard deviation of three replications.

biocontrol bacteria $B$. licheniformis $\mathrm{N} 1$, the culture broth of Strain N1 containing pWH43G with Silwet L-77 was applied to the strawberry plants in a controlled growth chamber.
Bacterial cells expressing GFP emitted green fluorescence and could be detected by CLSM. When bacteria with pWH1520 (vector control) plasmid were treated on the strawberry plants, no bacterial cells exhibiting with green fluorescence were detected (data not shown). No fluorescent cells could be detected in control plant tissues of strawberry, neither (Fig. 2). Initial colonization of the strain N1 was clearly recognized on leaves (Fig. 2A) and crowns (Fig. 2B), but was relatively lower on the petioles (Fig. 2C). One and three days after bacterial application, the bacterial cells were found to colonize the surfaces of all three investigated tissues, including trichomes on the petioles (Fig. 2C). During bacterial colonization on the plant surfaces, bacteria formed aggregates on the leaves and crowns, which was similar to bacterial biofilm formation. On the leaves and the crowns, bacterial aggregates were abundant in the peripheral area of individual epidermal cells (Fig. 2A and 2B). Bacterial colonization along the veins of leaves and crowns appeared to be much limited. The places at which high aggregations of the bacterial cells was observed might be the preferable location for bacteria to obtain some nutrients or to tolerate the harsh conditions on the plant surfaces. Fluorescent bacteria disappeared from 5 days after bacterial application on the leaves and petioles, but was stably maintained on the crowns. In general, bacterial colonization on the petioles appeared to be much less than on the leaves and crowns.

Persistence of $B$. licheniformis N1 on the strawberry plant treated with N1E formulation. In our previous study, we developed a wettable powder formulation using $B$. licheniformis $\mathrm{N} 1$ referred to as N1E which was highly effective to control gray mold disease in tomato and strawberry plants (Kim et al., 2007; Lee et al., 2006). Bacterial colonization and persistence of Strain N1 was investigated over time after application of N1E on the strawberry plant. When 100-fold diluted N1E was applied on the strawberry plants after addition of Silwet L-77 $(0.03 \%)$, the initial bacterial cells on the plants appeared to be approximately $10^{4} \mathrm{cfu} / \mathrm{g}$ of plant tissues (Fig. 3). In a growth chamber with consistent temperature and relative humidity of $25^{\circ} \mathrm{C}$ and $70 \%$, respectively, N1 seemed to colonize plant tissues and bacterial population was stably maintained for over 20 days (Fig. 3A). Even the bacterial population increased slightly compared to the initial attached population. In contrast, bacterial population on the plant in a plastic house under temperature fluctuation (temperature range of $10-25^{\circ} \mathrm{C}$ ) declined rapidly after 5 days from the bacterial application and no detectable viable cells were present on the plants 7 days after bacterial application, irrespective of the plant tissues (Fig. 3B). Any increase of bacterial population since initial attachment on 


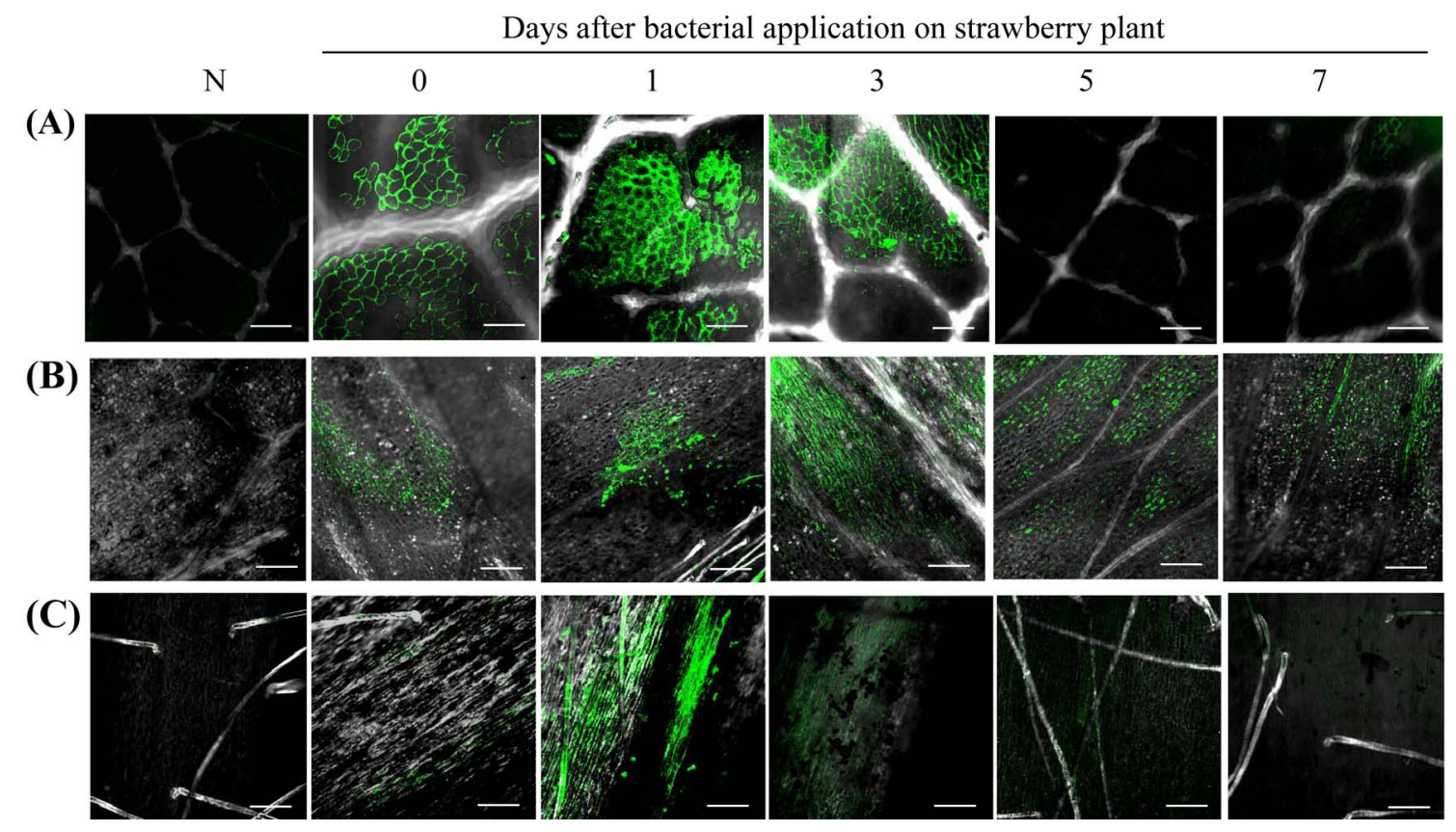

Fig. 2. Confocal laser scanning microscopy of the strawberry leaves (A), crowns (B) and petioles (C) colonized by $g f p$-labelled $B$. licheniformis N1. Images (100 X magnification) are overlays of GFP fluorescence (505-530 nm) and the transmitted light pictures. Days after bacterial application on the strawberry plants are indicated on top of the images from 0 day to 7 days. $\mathrm{N}$ represents the control without any bacterial application and no fluorescent cells were present in this control. Bar represents $80 \mu \mathrm{m}$.
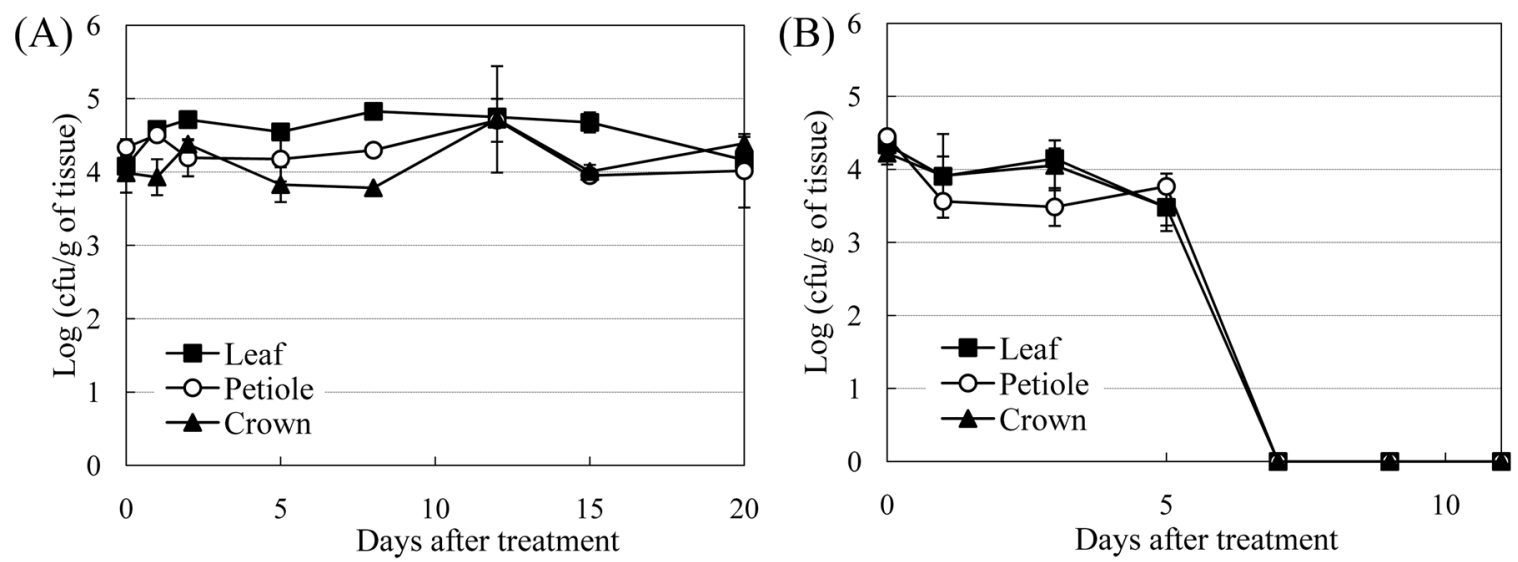

Fig. 3. Changes in the bacterial population of B. licheniformis N1 on the strawberry plant tissues (leaves, crowns and petioles) treated with 100 -fold diluted N1E containing $0.03 \%$ of Silwet L-77. (A) Experiments were performed in a controlled growth chamber. (B) Experiments were performed with the strawberry plants grown in a plastic house (temperature range of $10-25^{\circ} \mathrm{C}$ ). Error bars represent the standard deviation of three replications.

plant surface was not recognized in the plastic house.

\section{Discussion}

Bacterial population dynamics needs to be investigated to understand the bacterial activity on the plant surface environment and to predict the likelihood of successful biocontrol of foliar plant diseases before commercialization of biocontrol agent. Spatial and temporal distribution of a biocontrol bacterium $B$. licheniformis $\mathrm{N} 1$ was investigated on the strawberry plants in this study using bacterial culture and bacterial formulation of strain N1 called as N1E. Three tissues of the strawberry plant, such as leaves, crowns and petioles, are important tissues for the initial population growth of fungal plant pathogens, such as Botrytis cinerea and Colletotrichum gloeosporioides (Braun and Sutton, 
1988; Howard et al., 1992). Successful attachment and initial colonization of the bacteria on the harsh condition of plant surfaces would result in much less disease incidence in mature strawberry plant by decreasing fungal inoculums.

Our result suggested that Silwet L-77 may help bacteria to be stabilized on the plant surfaces. Silwet L-77 has been frequently used as an adjuvant for chemical applications (Gent et al., 2003) and it has been also utilized for biocontrol agent application on plants. Some Bacillus spp. treated together with Silwet L-77 resulted in long-term stable colonization of cacao leaves and Silwet L-77 facilitated substomatal infiltration of bacteria to allow for endophytic colonization (Melinick et al., 2008). In addition, Silwet L-77 was previously reported to induce short-term activation of plant defense response (Jetiyanon, 1994). Based on our result, it is not clear if Silwet L-77 facilitate bacteria to enter into plants or induce plant defense response. However, it is apparent that Silwet L-77 supplement to B. licheniformis strain N1 can improve bacterial persistence on plant surface. Our previous study (Kong et al., 2010) showed that $B$. licheniformis Strain N1 produces surfactin and iturin in vitro. Studies on surfactin production in Bacillus species showed that surfactin is involved in the bacterial attachment to the plant surfaces (Kinsinger et al., 2003; Leclère et al., 2006). It will be interesting to investigate whether surfactin production from strain N1 can contribute to the initial bacterial attachment on the plant surface. In the present study, the $g f p$ labelled Strain N1 exhibited bacterial colonization and cell aggregation on the strawberry leaves and crowns. Attachment and aggregation in microcolonies is the basis of plant surface colonization by bacteria and those microcolonies can be considered as a type of biofilm (Ramey et al., 2004). Spatial and temporal organization of the biofilms was observed with several B. subtilis isolates (Branda et al., 2001). The places at which high aggregations of the cells was observed would be the preferable location for bacteria to obtain some nutrients or to tolerate the harsh conditions on the plant surfaces. Bacterial cells move over the plant surface to reach new niches with more nutrients and moistures. The bacterial movement may allow the bacteria to spread as a biofilm over the plant surface, which is largely dependent on the production of biosurfactants (Bais et al., 2004; Daniels et al., 2004). Once established in the phytosphere, the bacteria can produce antifungal active compounds to suppress the disease (Ongena and Jacques, 2008).

Our result showed the relative longer persistence of GFP expressing bacteria on the crown, compared to leaves and crowns. Leaves and petioles of the strawberry plants are the exposed plant tissues which face a rapidly fluctuating environment (humidity, temperature and nutrient). Extra moisture and probably some nutrients can be accumulated in the crown area which may be the ideal place for bacteria colonization in comparison to the other tissues of the strawberry plants. In our previous study (Kong et al., 2009) and in Fig. 1 of this study suggested that plasmid pWH43G could not be maintained stably for an extended period of time. No fluorescence from B. licheniformis N1 carrying pWH43G after 5-7 days from the bacterial application on the leaves and petiole was detected, which might be due to plasmid instability.

It has been frequently recognized that Bacillus strains can persist well in the natural environments as compared to the Gram-negative bacteria because of endospore formation (Emmert and Handelsman, 1999). However, steadily continued harsh conditions with limited nutrients and changing climate on the plant surfaces would probably eliminate strain N1. Our result suggested that Strain N1 was not stably maintained on plant surfaces when they are exposed to the fluctuating environments, compared to the controlled environment (Fig. 3). A variety of environmental factors, such as temperature, relative humidity and the availability of nutrients, will influence bacterial persistence and activity in natural environments (Lindow and Brandl, 2003). The strain N1 could be under much less pressure to persist on the strawberry plant surface because of controlled environmental factors in the growth chamber, compared to those in plastic houses. Most likely, the plant surface of the strawberry may not be a natural habitat for $B$. licheniformis strain N1 in order to persist for a longer period of time in a fluctuating environment. Although similar experiments should be repeated during different seasons or in the field, our results suggest that the practical application of N1E to control strawberry gray mold or anthracnose should be repeated in a 5 or 7 days interval.

Here, we report the temporal and spatial distribution of strain N1 on the strawberry plants grown in a growth chamber or in a plastic house. Capability of strain N1 to attach to the plant surface and to colonize plant tissues of strawberry may be a good trait for it to be used as a biocontrol agent, together with iturin and surfactin production (Kong et al., 2010). However, the bacterial persistence should be improved when applied in a plastic house. Different formulations or treatment methods should be considered.

\section{Acknowledgments}

This study was supported by a grant (Code \#20080401034064) from the BioGreen21 program of the Rural Development Administration, Republic of Korea.

\section{References}

Bais, H. P., Fall, R. and Vivanco, J. M. 2004. Biocontrol of Bacillus subtilis against infection of Arabidopsis roots by Pseudo- 
monas syrignge is facilitated by biofilm formation and surfactin production. Plant Physiol. 134:307-319.

Branda, S. S., González-Pastor, J. E., Ben-Yehuda, S., Losick, R. and Kolter, R. 2001. Fruiting body formation by Bacillus subtilis. Proc. Natl. Acad. Sci. U.S.A. 98:11621-11626.

Braun, P. G and J. C. Sutton. 1988. Infection cycles and population dynamics of Botrytis cinerea in strawberry leaves. Can. J. Plant Pathol. 10:133-141.

Collins, D. P., Jacobsen, B. J. and Maxwell, B. 2003. Spatial and temporal population dynamics of a phyllosphere colonizing Bacillus subtilis biological control agent of sugar beet cercospora leaf spot. Biol. Control. 26:224-232.

Cook, R. J. 1993. Making greater use of introduced microorganisms for biological control of plant pathogens. Anпu. Rev. Phytopathol. 31:53-80.

Daniels, R., Vanderleyden, J. and Michiels, J. 2004. Quorum sensing and swarming migration in bacteria. FEMS Microbiol. Rev. 28:261-289.

Emmert, E. A. B. and Handelsman, J. 1999. Biocontrol of plant disease: a (Gram-) positive perspective. FEMS Microbiol. Lett. 171:1-9.

Fravel, D. R. 2005. Commercialization and implementation of biocontrol. Annu. Rev. Phytopathol. 43:337-359.

Fravel, D. R., Connick. Jr. W. J. and Lewis, J. A. 1998. Formulation of microorganisms to control plant diseases. In: Formulation of Microbial Pesticides: Beneficial Microorganisms, Nematodes and Seed Treatments, ed by H. D. Burges. pp 187202. Kluwer Academic Publishers, Dordrecht, The Netherlands.

Gent, D. H., Schwartz, H. F. and Nissen, S. J. 2003. Effect of commercial adjuvants on vegetable crop fungicide coverage, absorption, and efficacy. Plant Dis. 87:591-597.

Howard, C. M., Maas, J. L., Chandler, C. K. and Albregts, E. E. 1992. Anthracnose of strawberry caused by the Colletotrichum complex in Florida. Plant Dis. 76:976-981.

Jeger, M. J., Jeffries, P., Elad, Y. and Xu, X.-M. 2009. A generic theoretical model for biological control of foliar plant diseases. J. Theor. Biol. 256:201-214.

Jetiyanon, K. 1994. Immunization of cabbage for long-term resistance to black rot. M.S. thesis. Auburn University, Auburn, USA.

Kim, H. J., Lee, S. H., Kim, C. S., Lim, E. K., Choi, K. H., Kong, H. K., Kim, D. W., Lee, S-W. and Moon, B. J. 2007. Biological control of strawberry gray mold caused by Botrytis cinerea using Bacillus licheniformis N1 formulation. J. Microbiol. Biotechnol. 17:438-444.

Kinsinger, R. F., Shirk, M. C. and Fall, R. 2003. Rapid surface motility in Bacillus subtilis is dependent on extracellular surfactin and potassium ion. J. Bacteriol. 185:5627-5631.

Kong, H. G., Kim, J-C., Choi, G. J., Lee, K. Y., Kim, H. J., Hwang,
E. C., Moon, B. J. and Lee, S-W. 2010. Production of surfactin and itruin by Bacillus licheniformis N1 responsible for plant disease control activity. Plant Pathol. J. 26:170-177.

Kong, H. G., Choi, K. H., Heo, K. R., Lee, K. Y., Lee, H. J., Moon, B. J. and Lee, S-W. 2009. Generation of a constitutive green fluorescent protein expression construct to mark biocontrol bacterial using P43 promoter from Bacillus subtilis. Plant Pathol. J. 25:136-141.

Leclère, V., Marti, R., Béchet, M., Fickers, P. and Jacques, P. 2006. The lipopeptides mycosubtilin and surfactin enhance spreading of Bacillus subtilis strains by their surface-active properties. Arch. Microbiol. 186: 475-483.

Lee, K. Y., Heo, K. R., Choi, K. H., Kong, H. G, Nam, J., Yi, Y. B., Park, S. H., Lee, S-W. and Moon, B. J. 2009. Characterization of a chitinase gene exhibiting antifungal activity from a biocontrol bacterium Bacillus licheniformis N1. Plant Pathol. J. 25:344-351.

Lee, J. P., Lee, S-W., Kim, C. S., Son, J. H., Song, J. H., Lee, K. Y., Kim, H. J., Jung, S. J. and Moon, B. J. 2006. Evaluation of formulations of Bacillus licheniformis for the biological control of tomato gray mold caused by Botrytis cinerea. Biol. Control. 37:329-337.

Lindow, S. E. and Brandl, M. T. 2003. Microbiology of the phyllosphere. Appl. Environ. Microbiol. 69:1875-1883.

Maas, J. L. 1984. Compendium of Strawberry Diseases. American Phytopathological Society, St. Paul, MN.

Mathre, D. E., Cook, R. J. and Callan, N. W. 1999. From discovery to use: Traversing the world of commercializing biocontrol agents for plant disease control. Plant Dis. 83:972-983.

Melinick, R. L., Zidack, N. K., Bailey, B. A., Maximova, S. N., Guiltinan, M. and Backman, P. A. 2008. Bacterial endophytes: Bacillus spp. from annual crops as potential biological control agents of black pod rot of cacao. Biol. Control. 46:46-56.

Nam, M. H., Kim, H. S., Lee, W. K., Seong, Y. K., Gleason, M. L., Song, J. Y. and Kim, H. G. 2008. Application of an IPMbased spray program to protected cultivation of strawberry in Korea. Hort. Environ. Biotechnol. 49:352-356.

Ongena, M. and Jacques, P. 2008. Bacillus lipopeptides: versatile weapons for plant disease control. Trends Microbiol. 16:115125.

Ramey, B. E., Koutsoudis, M., von Bodman, S. B. and Fuqua, C. 2004. Biofilm formation in plant-microbe associations. Curr. Opin. Microbiol. 7:602-609.

Schisler, D. A., Slininger, P. J., Behle, R. W. and Jackson, M. A. 2004. Formulation of Bacillus spp. for biological control of plant diseases. Phytopathology 94:1267-1271.

Xue, G. P., Johnson, J. S. and Dalrymple, B. P. 1999. High osmolarity improve the electro-transformation efficiency of the gram-positive Bacillus subtilis and Bacillus licheniformis. $J$. Microbiol. Meth. 34:183-191. 